\title{
An Overview of Aniline and Chloroaniline Compounds as Environmental Pollutants
}

\author{
Vijayalakshmi A Edallii ${ }^{1}$, Kishor Sureshbhai Patil ${ }^{2}$, Ve Van Le ${ }^{2}$ and Sikandar I Mulla ${ }^{1 *}$ \\ ${ }^{1}$ Department of Biochemistry, Karnatak University, Dharwad, India \\ ${ }^{2}$ Department of Biotechnology, Chonbuk National University, Republic of Korea \\ *Corresponding author: Sikandar I Mulla, Department of Biochemistry, Karnatak University, Dharwad-580 003, India
}

Submission: August 13, 2017; Published: May 31, 2018

\begin{abstract}
Aniline and chloroaniline are widely used for the synthesis of many industrial useful chemicals. Hence, due to their vast use these chemicals are often observed in the eco-geological system. Because of their continuous long persistence in the environment they might be toxic to human beings, animals and aquatic system. In this review we discussed about their uses, pollution and toxic impact.
\end{abstract}

Keywords: Aniline; Chloroaniline; Environmental pollution; Toxicity

Aniline and Chloroaniline Compounds Uses, Environmental Pollution and their Toxicity

Aniline and its derivatives are used as mediators in most of different operational fields, for example, synthesis of dyes, plasticizers, pharmaceuticals, pesticides, polymers including polyurethane and rubber additives, photographic chemicals as well as varnishes and also as precursors for amino aromatic derivatives [1-6]. Due to their vast use they often found in the environment. For example, they formed as main intermediates during microbial transformation of nitroaromatic compounds, dinitroaniline, urea, herbicides, triclocarban (antimicrobial agent) and nitropyrenes etc., [7-9]. Activities of extracting of crude oil hydrocarbons frequently causes environmental pollution which might leads to unsafe results for living and non-living combinations of environments $[10,11]$. If aniline is dispersed in soil, it can quickly enter into the underground water and/or evaporate to an average extent. Hence, in view of the biological accumulation, long term deposit and carcinogenic properties, it might have impact on living systems [12]. Furthermore, anilines and chloroanilines accumulate in soil, undergo numerous spontaneous chemical transformations and turn into nonextractable humic acid like compounds and/orxenobiotics [13-16]. Xenobiotics are released into the ecosystem via manufacturing wastewaters and their direct application to soil resulting in the introduction of carcinogenic and mutagenic chemicals to the ecogeological system. Their prevalence in the surroundings leads to bioaccumulation and can interrupt the conservation balance of the microbial system in soil. Such accumulation in the long run may be hazardous/toxic to the human's health. On the other hand, xenobiotics are found to be toxic and carcinogenic to living systems [17]. Due to their wide-ranging of toxic impact and carcinogenicity, wastewater containing aniline compound is classified as hazardous waste [10]. The main toxic effects of aniline start with the creation of methemoglobin in blood are expressed by dropping of oxygen carrying, anaemia, jaundice, damage of liver, spleen plus lungs and reduced blood coagulation $[18,19]$. Chloroanilines are toxic compounds which hinder oxidative phosphorylation and microbial growth. As a membraneotropicmaterial, 4-chloroaniline affects the activity of membrane bound enzymes involved in biosynthesis of lipid molecules [20].

Wastewater containing aromatic amines likes aniline and chloroaniline has been shown to be treated by photolysis, bipolar membrane microbial electrolysis cell-Fenton system, resin adsorption, advanced oxidation processes and microbial biodegradation methods. On the other hand, they are not completely decomposed by activated sludge process and also inhibit biodegradation of other chemicals due to their hard biodegradability in the ecosystem. Hence, there is a need of organisms having the ability to remove these chemicals.

\section{References}

1. Afzalkhan S, Hamayun M, Latif KA, Ahmad B, Ahmed S, et al. (2009) Influence of $\mathrm{pH}$, temperature and glucose on biodegradation of 4-aminophenol by a novel bacterial strain, Pseudomonas sp. ST-4. African Journal of Biotechnology 8(16): 3827-3831.

2. Gheewala SH, Annachhatre AP (1997) Biodegradation of aniline. Water Science and Technology 36(10): 53-63. 
3. Jiang Y, Shang Y, Zhou J, Yang K, Wang H (2016) Characterization and biodegradation potential of an aniline-degrading strain of Pseudomonas JA1 at low temperature. Desalination and Water Treatment 57: 25011. 25017.

4. Li GY, Lu AH, Gao X (2003) An investigation into the oxidation and degradation of phenol in water by natural cryptomelane. Acta Petrologicaet Mineralogica 22: 162-166.

5. Sihtmae M, Mortimer M, Kahru A, Blinova I (2010) Toxicity of five anilines to crustaceans, protozoa and bacteria. Journal of the Serbian Chemical Society 75(9): 1291-1302.

6. Yen JH, Tsai PW, Chen WC, Wang TS (2008) Fate of anilide and aniline herbicides in plant-materials-amended soils. J Environ Sci Health B 43(5): 382-389.

7. Hallas LE, Alexander M (1983) Microbial transformation of nitroaromatic compounds in Sewage Effluent. Appl Environ Microbiol 45(4): 12341241.

8. Kinouchi T, Ohnishi Y (1983) Purification and characterization of 1-nitropyrene nitroreductases from Bacteroides fragilis. Applied and Environmental Microbiology 46(3): 596-604.

9. Mulla SI, Hu A, Wang Y, Sun Q, Huang SL, et al. (2016) Degradation of triclocarban by a triclosan-degrading Sphingomonas sp strain YL-JM2C. Chemosphere 144: 292-296.

10. Ahmed S, Nisar MF, Hussain K, Majeed A, Ghumroo PB, et al. (2010) Isolation and characterization of a bacterial strain for aniline degradation. African Journal of Biotechnology 9(8): 1173-1179.

11. Okoh A (2006) Biodegradation alternative in the cleanup of petroleum hydrocarbon pollutants. Biotechnology and Molecular Biology Review $1(2): 38-50$.
12. Li X, Jin X, Zhao N, Angelidaki I, Zhang Y (2017) Efficient treatment of aniline containing wastewater in bipolar membrane microbial electrolysis cell-Fenton system. Water Research 119: 67-72.

13. Delnavaz M, Ayati B, Ganjidoust H (2008) Biodegradation of aromatic amine compounds using moving bed biofilm reactors. Journal of Environmental Health Science and Engineering 5(4): 243-250.

14. Parris GE (1980) Environmental and metabolic transformations of primary aromatic amines and related compounds. Residue Reviews 76: $1-30$.

15. Pillai P, Helling CS, Dragun J (1982) Soil-catalysed oxidation of aniline. Chemosphere 11(3): 299-317.

16. Winnie D, Johan G, Ann D, Veerle DD, Katrien C, et al. (2002) Diversity of 3-chloroaniline and 3,4-dichloroaniline degrading bacteria isolated from three different soils and involvement of their plasmids in chloroaniline degradation. FEMS Microbiol Ecol 42(2): 315-325

17. Zhang T, Zhang J, Liu SJ, Liu ZP (2008) A novel and complete gene cluster involved in the degradation of aniline by Delftia sp. AN3. Journal of Environmental Sciences 20(6): 717-724.

18. Fashola MO, Obayori OS, Omotayo AE, Adebusoye SA, Amund 00 (2013) Biodegradation of p-chloroaniline by bacteria isolated from contaminated sites. International Research Journal of Microbiology $4(1): 38-45$

19. Mucha K, Kwapisz E, Kucharska U, Okruszek A (2010) Mechanism of aniline degradation by yeast strain Candida methanosorbosa BP-6. Pol J Microbiol 59(4): 311-315.

20. Mysyakina IS, Funtikova NS (2000) Lipid composition of the yeast like and mycelia Mucor hiemalis cells grown in the presence of 4-chloroaniline. Microbiology 69(6): 670-675.
Creative Commons Attribution 4.0 International License

For possible submissions Click Here

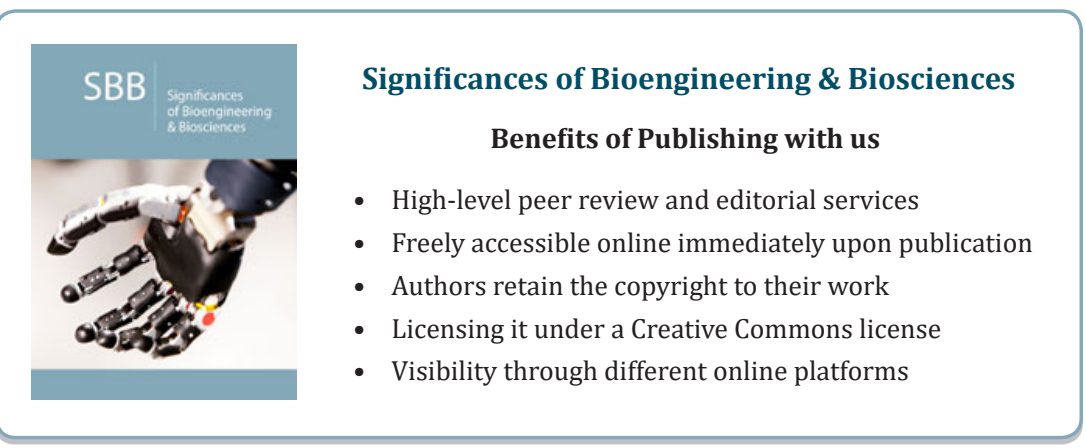

